\title{
An Insight into the Diversity of Mr. Dick’s Roles in David Copperfield
}

\author{
Xiaohua Li \\ School of Foreign Languages, Qingdao University of Science and Technology, Qingdao, China \\ Email: magyan@sohu.com
}

\begin{abstract}
In David Copperfield, Mr. Dick has played a diversity of roles. He serves not only as a comic figure who brings absurdity and laughter to these harsh experiences, a representative of innocence in disguise of a mentally disabled man, but also as a necessary mental counselor and a domestic helper to others. By exploring those roles to their fullest Charles Dickens has created a unique character that is enchanting as well as complicated.
\end{abstract}

Index Terms - comic, innocence, mental counselor, domestic helper, good

\section{INTRODUCTION}

In David Copperfield, Mr. Dick has a pretty tragic back-story: when his father died, his will requested that Mr. Dick's brother look after Mr. Dick. But Mr. Dick's brother was ashamed of him, and refused to let Mr. Dick share his house. So, he sent Mr. Dick away to an asylum-which, in the nineteenth century, were brutal, awful places where patients were frequently mistreated. So, Mr. Dick grew very ill. Miss Betsey rescued Mr. Dick and took over his guardianship.

Despite his pitiable background, Mr. Dick has several important roles to play. He is not only a comic figure who entertains people, a man of innocence in disguise of mental disability, but also a mental counselor who offers moral guide and support to both Miss Trotwood and Mr. David Copperfield.

\section{A DIVERSITY OF ROLES}

\section{A. A Comic Figure}

Mr. Dick, a comic figure in David Copperfield, who is in sharp contrast with other adult male characters in the novel, is both a man and a boy. Gerald (2003) holds that Mr. Dick is described as "a young mind in an adult body" (P.93) Like a boy, he is unable to control his impulses or order his thoughts. When David Copperfield first meets him, Mr. Dick has nearly scared the boy into running away from the house. Mr. Dick goes downstairs and greets the shabby child with a squinting eye and odd mix of shaking and nodding head movements, which immediately illustrates a funny character who offers ridicule and laughter to readers.

More than that, Mr. Dick is a writer whose life is devoted to writing a Memorial of King Charles, a memorial that he destroys as soon as he writes it, much as Penelope did weaving and unweaving her tapestry. He had been spending more than ten years trying to keep King Charles the First out of the Memorial; but he had been constantly getting into it, and is there now. All this makes him such a comic figure of ridicule and absurdity.

Besides being a funny writer, Mr. Dick is a man-child who delights in building and flying kites. He has the hobby of turning failed project pages into kites so that "he can fly and by doing so he believes he can disseminate his half-baked ideas at least the locals."(Dickens, P.211) One day Mr. Dick invites David to go fly with him his new creation-a seven feet high kite! The kite is covered with the very same manuscript that the innocent soul has written:

"There's plenty of string," said Mr. Dick, "and when it flies high, it takes the facts a long way. That's my manner of diffusing 'em. I don't know where they may come down. It's according to circumstances, and the wind, and so forth; but I take my chance of that." (ibid., P.212)

In that magical dimension in which Mr. Dick lives, he imagines and predicts that "words -which he calls facts- not only live, fly, soar, and travel in space, but that also have consequences which a writer cannot foresee"(ibid., P.212). In a century in which radio, TV, satellite, and other special communication was unknown, only a man of imagination could have foreseen that.

As a result, Mr. Dick manifests a comic ability of laughter and absurdity yet a unique ability of imagination.

\section{B. Man of Innocence}

Apparently, Mr. Dick is a man of innocence in disguise of his mental disability. Halliwell (2004) concludes that "The angelic innocence is vividly personified in the insane Mr. Dick.” When David first meets Mr. Dick, he begins to suspect that Dick is slightly mad because as Mr. Dick writes his auto-biography, he claims to have trouble keeping King Charles I out of it! Later in the novel, Mr. Dick tells David that he has a simple mind. When he notices the "vacant manner, his submission to aunt, and his childish delight when she praised him," in Mr. Dick, David begins to "suspect him of being 
a little mad." (Dickens, P.189)

However, Miss Trotwood is very used to hearing other people's negative judgments about him. In this sense, Miss Trotwood is a pioneer in her treatment of the intellectually disabled. She insists on taking care of Mr. Dick by herself instead of sending him to the asylum. In addition to that, she always tries to deny the existence of mental disability in Mr. Dick. That's why Miss Trotwood affirms repeatedly of Mr. Dick's "sound advice" and "common sense", thus making this character increasingly funny (Dickens, P. 207) Nevertheless, she admits the apparent need to correct Dick's funny behavior. Miss Trotwood becomes upset with his impropriety.

"Mr. Dick," said my aunt, "don't be a fool, because nobody can be more discreet than you can, when you choose. We all know that. So don't be a fool, whatever you are ...you have heard me mention David Copperfield? Now don't pretend not to have a memory, because you and I know better." (ibid., P.188)

It is obvious that Miss Betsy, David Copperfield, and others know that Mr. Dick is mad. Nevertheless, Mr. Dick is portrayed as a man of innocence. While sane people tend to see reality as it is or should be, characters like Mr. Dick see the reverse side of it. And who is to say that the reverse side of things is not the real side. While eccentrics, madmen, and artists retain that child-like virtue of seeing in that elusive magical dimension, most of us lose it. And with that we lose innocence, our sense of high moral and a good and true heart. Although in David Copperfield many of Dickens's characters are considered insane, "those characters who are crazy are often likewise of high moral quality and a good heart." (Wright ,2001)

\section{Mental Counselor}

Despite his mental disability, in his process of maturation, Mr. Dick represents a model of a mature adult who is not handicapped by the cruelties of the world. Dick is a moral counselor to Miss Trotwood and Mr. Copperfield. Throughout the story, Miss Trotwood is not treating Mr. Dick only out of pity. To her, Mr. Dick means more than a comic figure or an object of pity. When confronted with important problems she always asks Mr. Dick for advice. The underlining reason is that Mr. Dick always echoes what Miss Trotwood has believed to be correct yet not uttered and offers simple and spontaneous solutions to difficult situations. In other words, both Mr. Dick and Miss Trotwood believe in Christian morals and humanity. As a result, the strong-willed and sensible Miss Trotwood has total confidence in the man's wisdom. Therefore, strangely enough Mr. Dick becomes a "wise" 10 man and a necessary counselor who supplies Miss Trotwood with seemingly irrelevant but simple and direct suggestions that stimulate her to act immediately. These complicated human problems are nothing but simple events which only need simple answers.

When she asks Mr. Dick what she should do with the ten-year-old David who has come to her house in rags, he suggests, "wash him!" (Dickens, P. 189). Later, facing the seemingly legal demands from the cruel Mr. Murdstone to hand over his stepson, Miss Trotwood again asks Mr. Dick what she should do with Copperfield. Mr. Dick responds spontaneously with another gem: "Have him measured for a suit of clothes directly" (ibid., P. 207). In both difficult situations, Mr. Dick defies the traditional social norms and suggests some seemingly irrelevant, unexpected and naïve solutions which turn out to go hand in hand with the basic Christian doctrines. That's why Miss Trotwood says, "because you and I know better." (ibid., P. 188)

From what she has said, we come to five facets of meanings. First, it represents the existence of Mr. Disk as a necessary moral counselor. Secondly, it signals Miss Trotwood's own need of mental supporter which her single life lacks. Thirdly, it is evident that Miss Trotwood has a sharp understanding of Dick's mental disability. Fourthly, it proves her eagerness to correct his impropriety. Last, it illustrates her possession of independent and sensible judgments. Though her comments on Mr. Dick are contradictory, Miss Trotwood affirms his functions as a mental counselor. In the end Miss Betsy always follows Mr. Dick's advice because in his humanness Mr. Dick is never wrong.

Furthermore, Mr. Dick demonstrates the power of love over cruelty within the moral framework of the novel. Mr. Dick's love for David and Miss Betsey gives his character moral credibility throughout the novel. In the closing chapters of David Copperfield, Mr. Dick becomes heroic in his own right, demonstrating the supremacy of simplicity and gentleness over cunning and violence. In this way, he shows that craftiness does not belong to maturity or adulthood - an important lesson for David as he becomes a man. With no surprise, Holmes (2004) states that Mr. Dick has been providing Copperfield with a moral yardstick against which he measures himself.

\section{Domestic Helper}

Mr. Dick has one other major role to play in this novel, that is a domestic helper. He becomes close friends with David's headmaster, Doctor Strong. He believes that Doctor Strong is the finest scholar that ever lived and listens patiently to Doctor Strong reading out from his Dictionary. He's such a loyal friend to Doctor Strong that when he notices that there is some kind of strain between Doctor Strong and his wife, Mr. Dick decides to bring them together at the right time. He announces this plan to David in really intriguing terms: "A simpleton, a weak-minded person [...] may do what wonderful people may not do. I'll bring them together, boy. I'll try. They'll not blame me. They'll not object to me. They'll not mind what I do, if it's wrong. I'm only Mr. Dick." (Dickens, P. 259) From his announcement, we can see that Mr. Dick, though a mentally disabled man, is intending to help with the domestic affairs outside the usual social structures of Dickens's novel.

We come to realize the dramatic moment at which the foolish, good-natured Mr. Dick attempts to reconcile the Strongs, who have been torn apart by unvoiced suspicions as to young Mrs. Strong's infidelity with his childhood 
sweetheart, the wastrel Jack Maldon. Annie Strong, who is kneeling in earnest pray before her donnish, somewhat can hardly understand her husband emotionally. Dr. Strong seems rather surprised when his wife was begging earnestly before him. More than that, he is even more surprised at Mr. Dick's kind interruption. Besides the numerous reference books and loose papers that clutter around Dr. Strong's desk, David and Aunt Betsey are witnesses to such a domestic drama. In contrast to the serious subject of marital reconciliation at the right, to the left is "our military friend" and "old soldier" Mrs. Markleham, Annie Strong's snobbish mother, who has consistently has biased opinion about her daughter's marriage. When she curiously looks up from her newspaper she instinctively scolded her daughter to rise rather than abase herself before her husband. She is lit by the scene's only obvious source of illumination, the candle to the extreme left, but she remains emotionally and intellectually in the dark as to the significance of the scene Dr. Strong is awakened not only by his faithful wife but more by the amiable, simple- minded Mr. Dick. Mr. dick gently, tentatively rouses Dr. Strong with his upstage hand and he gestures downward with his right to bring Annie to her husband's attention, so that he seems to be saying, "Doctor! . . . What is it that's amiss? Look here!" (ibid., P. 266). In some way, Mr. Dick is free from the constraints of society that he has a freedom and flexibility to interact with people's domestic affairs that even Miss Betsey and David do not have. And Mr. Dick is aware of his power. He uses this social flexibility to bring Mrs. Strong into the room where her husband is drafting his will at just the right time. Therefore, his role as a domestic helper is highly important.

\section{E. Man of Good}

The diversity of Mr. Dick's roles represents Dickens' revolutionary belief in good, which is in sharp contrast to traditional beliefs. Puccinelli (1995) states that the possession of high moral and a good heart does not necessarily lie in sanity and reason. A comic and mentally disabled figure like Mr. Dick can become the mental counselor to the sensible and the educated. In David Copperfield, Dickens rejects the conventional logic of the external world as the markers of high moral, rejects social position and education as markers of good, he likewise rejects sanity as a marker of maturity. Instead, he focuses on the innocence, in other words purity, of Mr. Dick's intentions and his willingness to follow his own heart and his instinctive convictions. Thereby Mr. Dick becomes such an enchanting character who has fully exemplified Dickens' revolutionary belief in being good.

\section{CONCLUSION}

Therefore, Mr. Dick in David Copperfield serves not only as a clown who brings absurdity and laughter to these harsh experiences, but also as a moral counselor who provides humane suggestions to both Miss Trotwood and Mr. Copperfield. Mr. Dick, who is a bit crazy, is a man of innocence with high moral quality and a good heart. Therefore, with the diversity of roles Mr. Dick becomes an enchanting yet complicated character who fully represents Dickson's insight into the possession of high moral and good in a man's innocence.

\section{REFERENCES}

[1] Schmidt, Gerald. (2003). A Likely Lad...For Many Purposes": The Use of Naivety in Barnaby Rudge and David Copperfield. Dickens Quarterly. 20: 93-107.

[2] Dickens, Charles. (1990). David Copperfield. London: Oxford World Classics.

[3] Tick, Stanley. (1969). The Memorializing of Mr. Dick. Nineteenth-Century Fiction. 24 (Sept.): 142-53.

[4] Halliwell, Martin. (2004). Images of Idiocy: The Idiot Figure in Modem Fiction and Film. Cornwall: Ashgate.

[5] Wright, David. (2001). Mental Disability in Victorian England: The Earlswood Asylum 18471901. Oxford: Clarendon Press.

[6] Holmes, Martha Stoddard. (2004). Fictions of Affliction: Physical Disability in Victorian Culture. Ann Arbor: U of Michigan.

[7] Puccinelli, Patricia M. (1995). Yardsticks: Retarded Characters and Their Roles in Fiction. New York: Peter Lang.

Xiaohua Li was born in Xi'an, China in 1970. He received his M.A. degree in linguistics from Beijing University, China in 2000.

$\mathrm{He}$ is currently a professor in the School of Foreign Languages, Qingdao University of Science \& Technology, Qingdao, China. His research interests include SLA and literature. 